\title{
The Urban Canvas: Urbanity and Painting in Maison Curutchet
}

\author{
ALEJANDRO LAPUNZINA \\ University of Illinois at Urbana-Champaign \\ USA
}

\begin{abstract}
This paper proposes a reading of the façade of Maison Curutchet, a significant yet largely unstudied building designed by Le Corbusier in 1949, as a metaphor or a condenser of the architect's ideas on urban-planning and painting. It also proposes that in this building Le Corbusier proved to be (contrary to what is often asserted) one of the most contextually urban oriented architects of the twentieth century.
\end{abstract}

\section{INTRODUCTION}

Maison Curutchet is undoubtedly one of the least known buildings designed by Le Corbusier. The reasons for the little attention that this work received from critics and historians to-date are manifold, and should be attributed to the building's geographical location, far away from what were then the centers of architectural production (the discourse and the literature of architecture), and to the insertion of the building within the architect's oeuvre, that is, a building contemporaneous to other major buildings and projects such as the Unite d'Habitation in Marseilles, the Duval Factory and the Masterplan for St. Dié, and the project for a vacation complex in the Mediterranean known as Roq et Rob. It is not surprising then that, due to its proximity to such masterpieces and its distant geographical location, Maison Curutchet remained largely ignored and unstudied.

However, this rather small building is very significant within Le Corbusier's oeuvre to the point of representing both a turning point in his design houses and a significant example of a particular period (1946-1954) in the architect's work, which William Curtis has considered as "as fruitful as the twenties and characterized by a mellow assessment of timeless values and an obsession with the harmony of nature." In effect, Maison Curutchet is the result of the crossbreeding of earlier prototypical schemes for the modern house proposed by Le Corbusier in the beginning of his architectural career, such as the Dom-Ino concept and Maison Citrohan, as well as it incorporates the architect's new discoveries, most notably the brise-soleil and the Modulor. ${ }^{2}$

\section{A BRIEF HISTORY AND DESCRIPTION OF MAISON CURUTCHET}

In September 1948, Dr. Curutchet, a well-known progressive surgeon from Argentina, contacted Le Corbusier, however indirectly, requesting his architectural services for the design of a combination of single family dwelling and medical office in a site, facing a beautiful large urban park, that he owned in the city of La Plata, one-hundred kilometers south of Buenos Aires. ${ }^{3}$ He sent to Le Corbusier a very detailed program of his needs that included a three- bedroom house with all "modern comforts," and an independent medical cabinet consisting of waiting room and consultation office where he could perform minor surgical interventions implementing his then revolutionary techniques.

In spite of being extremely busy with the design and construction of other major projects (most notably the Unité d'Habitation in Marseilles and the Masterplan for St. Dié) Le Corbusier immediately accepted this rather small commission from his unknown client, a fact that may be linked to the contemporaneous consideration by the government of Argentina of his Plan Regulateur de Buenos Aires. ${ }^{4}$ However, due to unforeseen delays in establishing an appropriate method of payment for his architectural fee, the design phase did not start until February 1949. On February 2, 1949, exactly one day after receiving the confirmation that his fee had been deposited in-full in an Argentinean bank, Le Corbusier conformed a "Curutchet team" with Roger Aujame (a former collaborator who was then working for the contractor at the Unité's site in Marseilles), and Bernard Hoesli, who had recently arrived to the Atelier.

The design of the building was completed in a rather short period of time and by the end of April 1949 a complete set of design drawings was ready. A few weeks later it was shipped to Dr. Curutchet, who received it enthusiastically. Meanwhile, in Argentina, Dr. Curutchet had selected Amancio Williams (a well-known Argentinean modern architect) as the site-architect from a list of four candidates proposed by Le Corbusier. Williams' responsibilities included the production of working drawings and the supervision of construction of the house. However, due to a long 
sequence of financial difficulties and serious polemics and misunderstandings between the client and his site-architect, the construction of the building did not start until more than one year later.

Eventually, the building was built in several phases, which coincided with the successive replacement of construction companies and site-architects. Once the concrete structure was completed Williams was replaced by Simón Ungar, who had initially a very good relationship with the client but was later fired by Dr. Curutchet. Moreover, the building faced several technical and financial problems during the construction phase and it demanded continuous and expensive repairs even before it was completed.

Finally, after six long years since the initial contact with Le Corbusier, the Curutchets occupied the completed house in 1954, and lived in it for approximately a decade. In the mid-sixties the family moved back to Loberia, a small town located $600 \mathrm{~km}$. away from La Plata, leaving the house virtually abandoned, used only as overnight accommodation for Dr. Curutchet during his then frequent trips to La Plata. In the late seventies and eighties the building was used for the same purpose only a very few days per year. In 1986 it was declared a National Monument, one year later it was fully restored, and for slightly more than one year became the headquarters of the Fundación Christmann, an institution created in the memory of Dr. Christmann, a plastic surgeon and friend of Dr. Curutchet. Nowadays, it is still owned by Dr. Curutchet's family, and since 1991 it houses the headquarters of the Province of Buenos Aires' Professional Association of Architects.

The functional and spatial resolution of the building is remarkable. The site was an existing empty container defined by three party walls, a ready available box, which Le Corbusier filled with a masterful display of his architectural elements and principles, as well as with the whole drama of his spatial poetry.

The conceptual scheme of the building consisted in the separation of the two functional units - clinic and dwelling-into two differentiated volumes connected function-

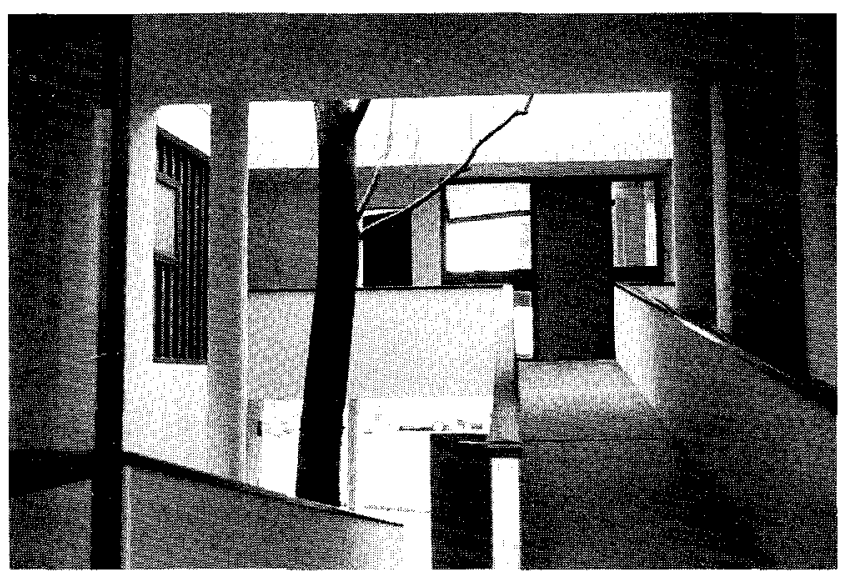

Fig. 1. Maison Curutchet, La Plata, Argentina; view from the ramp's landing. ally and spatially by a ramp. Arguably, the key to the functional and spatial organization of the building is the longitudinal section: a carefully calculated sequence of overlapping horizontal planes, trays, solid and void spaces that articulate the separation of the two units, yet provide cohesiveness to the whole.

The ground floor is virtually empty, housing only areas for traffic - garage, pedestrian entrance, ramp- and vegetation. The clinic is located in the first floor and, bridging across the site's entire width, occupies the frontal part of the plot. The dwelling is a nearly perfect cube located behind the clinic and suspended two levels above ground. Above the clinic, there is an outdoors terrace directly accessible from the social areas of the dwelling.

As it was typical of Le Corbusier's design modus operandi, Maison Curutchet served as a laboratory for testing his ideas for the modern epoch, from the large scale urban proposals to an aesthetic discourse rooted in the visual arts. The resolution of Maison Curutchet is, precisely, a very didactic demonstration of those characteristics of Le Corbusier's architecture. The building may be seen as both a metaphor at the scale of a single family dwelling of his proposals for urban planning, as well as a three-dimensional implementation of his painting principles, particularly those deriving from the Purist programme. Moreover, with this building Le Corbusier demonstrated the importance that he gave to the particularities of context, for, in Maison Curutchet, he responded to the characteristics of neighboring buildings by intentionally merging the building into the urbanity of the street's façade without abandoning his architectural principles and grammar.

All these aspects, the metaphor of the city, the spatial conception rooted in painterly principles, and the contextual urbanity of the building, can be clearly read, as if it were a demonstration, in the building's façade, which must be understood not as the plane where the building meets the street, but rather, as the visual collapsing, the telescoping and compression upon the observer's visual field of the spatial layering of the building.

\section{MAISON CURUTCHET AND THE METAPHOR OF URBAN PLANNING}

A very general summary of Le Corbusier's ideas on urban planning contemplated the separation of vehicular and pedestrian circulation, the liberation of the ground floor and its designation as an area of traffic, the horizontal stratification of motionless areas for living and working above the ground level, and the recuperation of the built area at the top of buildings for gardens and leisure activities. ${ }^{5}$

The resolution of Maison Curutchet clearly demonstrates these planning principles: the liberated ground floor is exclusively dedicated to circulation (entry gate, garage, ramp, path); the upper levels house the motionless areas for working and living; and, the top of the building (in this case the top of the clinic volume) is re-gained as an outdoor 

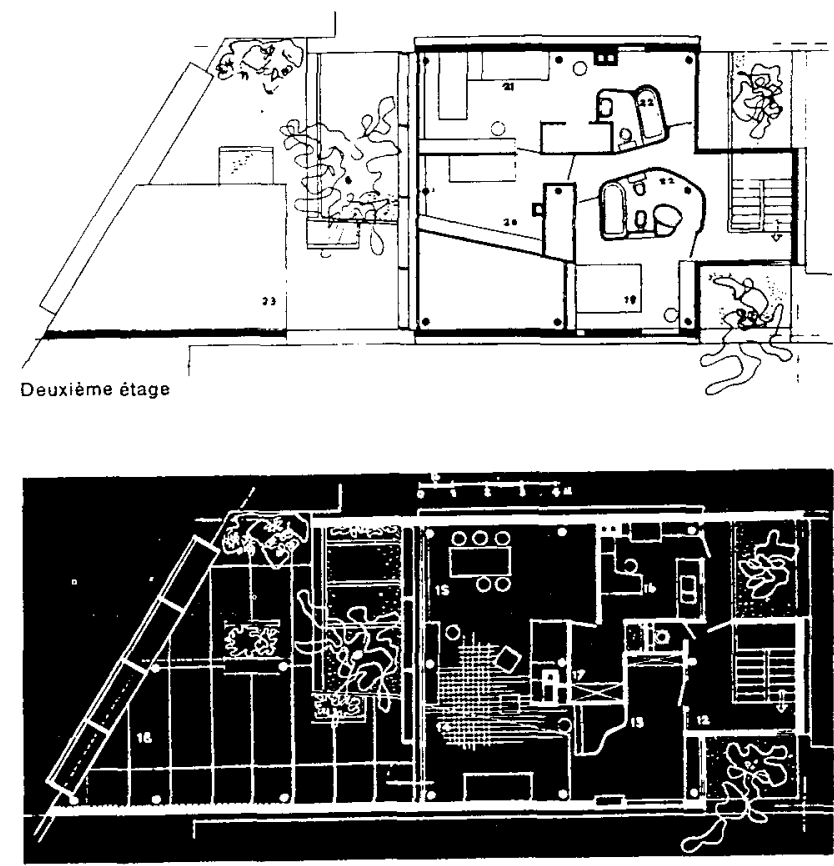

Premier étage

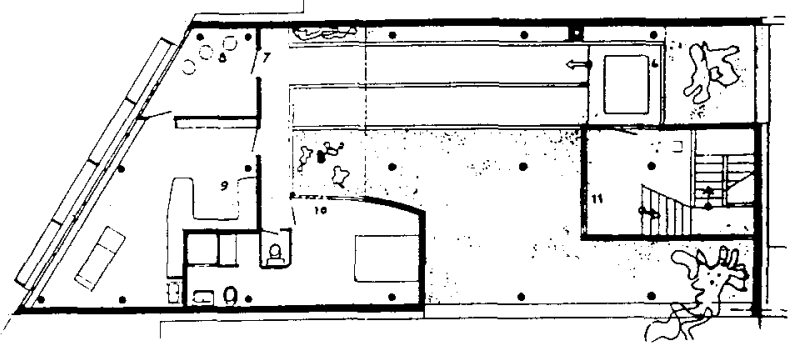

Entresol
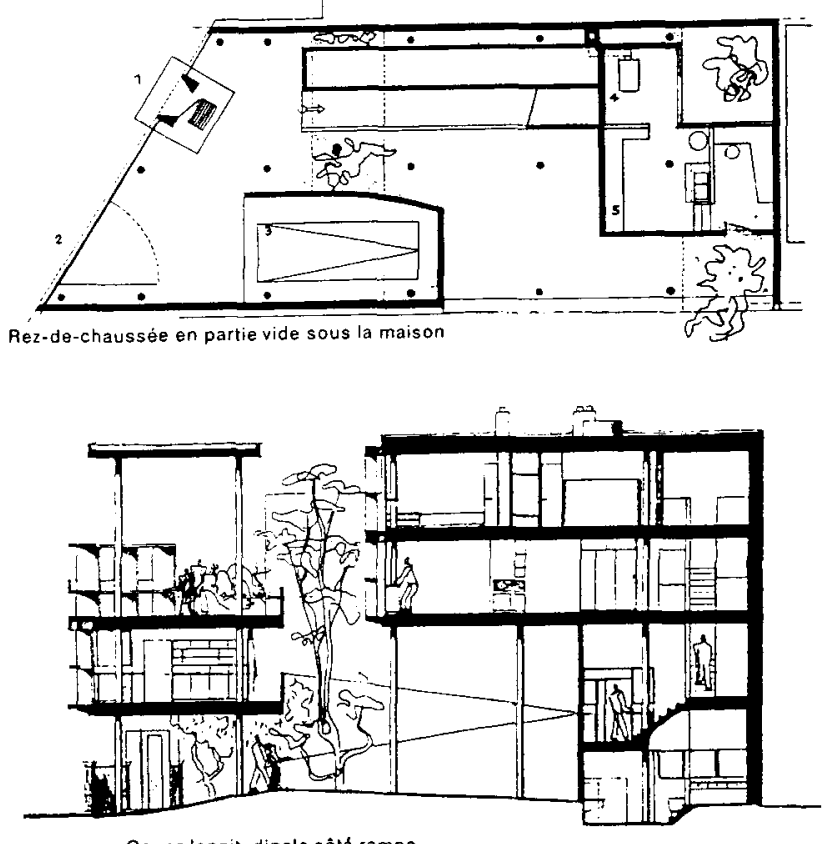

Coupe longitudinale côté rampe

Fig. 2. Maison Curutchet, floors plans and longitudinal section terrace that opens towards the extensive openness of the park, the infinite horizon of the pampas.

However, if (in Le Corbusier's own words) the plan is the generator of both the movements through the building as well as of its spatial layering, it is in the façade, the most visible and therefore the most public element of the building, that the whole discourse is clearly articulated. Vehicular and pedestrian circulations are clearly differentiated: the car enters on the right side, pedestrians on the left, where a concrete gate is the punctual element that clearly indicates the exact point of penetration to the building, the only interruption to an otherwise dark and recessed horizontal band. Once within the site's boundaries, in an area that remains neither interior nor exterior space, the garage remains on the right, while the pedestrian ramp and other paths remain on the left. This aspect of Maison Curutchet, which may be misunderstood as just a simplistic justification of a rather unavoidable functional resolution, is, nevertheless, firmly rooted in Le Corbusier's programmatic principles for the city, where body and machine remained separated, their territorial domains clearly differentiated.

The differentiation between the traffic level and the motionless upper levels is further articulated in the horizontal stratification of the façade's planes, which now may be

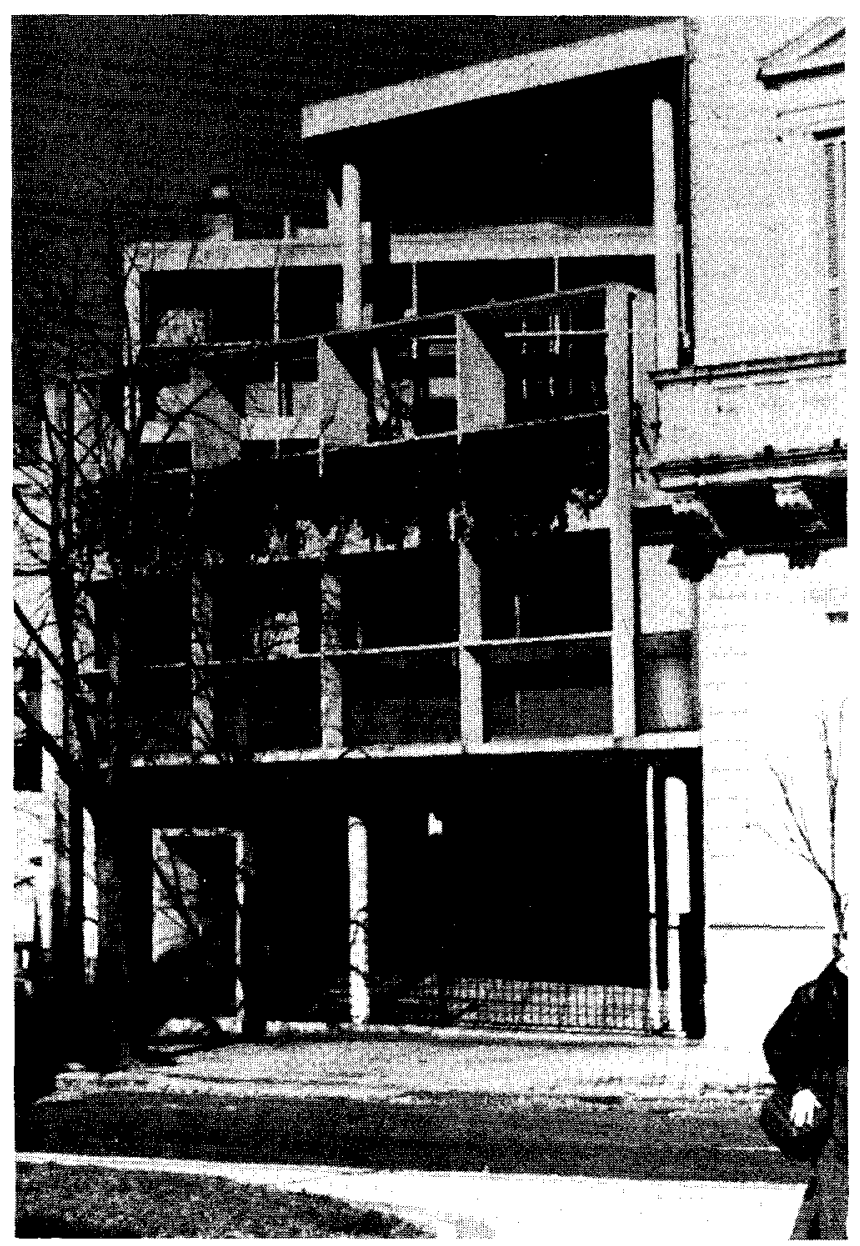

Fig. 3. Maison Curutchet, exterior 
understood as an advertisement, a sign that demonstrates the architect's postulates. The dark yet permeable lower band is clearly different from the upper bands, punctuated by the elements that explain this differentiation: gates for access and pilotis for detaching the habitable levels from both the damp earth and the traffic areas. Above the dark band there are two nearly identical brise-soleils that protect (the act of protection as a sign of habitation) the motionless areas. The two brise-soleils demarcate these areas of living and working, dwelling and clinic, as two separate components of the one single whole.

Finally, in the space between the two brise-soleils, rising from the ground and traversing through the volume of the clinic, four pilotis topped by a concrete roof, a baldachino, an open tent, crowns the front of the building on the right side. This baldachino, in conjunction with the extension upwards of the clinic's brise-soleil, demarcate an area for outdoor expansion that frames views and opens towards the beautiful park. Together, baldachino and brise-soleils constitute unequivocal signs that the top of the clinic has been regained and designated as a place for leisure activities, recuperating the area that the building occupies on the ground floor. ${ }^{6}$

\section{THE THREE-DIMENSIONAL CANVAS}

Maison Curutchet is also a very good example of the influence and importance that the architect's painting activity, particularly the principles derived from Purism, had in the development of his architecture.

Le Corbusier's Purist paintings were markedly nonperspectival, they favored a single and unchanging vantage point. In them, mundane objects of every-day reality were depicted in images that resembled their plan and section/ elevation. This juxtaposition and vertical correspondence of the object's top and frontal views reaffirmed that the viewpoint shifted exclusively in the vertical dimension, a frank opposition to Cubist strategies of simultaneously seeing the object from various vantage points.

Another characteristic of Purist painting was that the objects depicted were uniformly illuminated; this uniform illumination dissolved the three traditional painting-grounds (foreground, middleground, background), compressing them in vertical slices that succeeded and juxtaposed, one in front of the other, upon the picture-plane.

In very broad terms, Purist painting may be characterized by:

- the layered sequence of vertical planes upon the picture plane;

- the dissolution of the three traditional grounds in painting: foreground, middle-ground and background; and

- the utilization of determined compositional strategies. ${ }^{7}$

In clear correspondence with those Purist pictorial principles, Maison Curutchet is spatially organized as a sequence of parallel layers compressed upon the frontal plane. In effect, the building's areas are accommodated in spatial slices that succeed one in front of the other, not unlike the

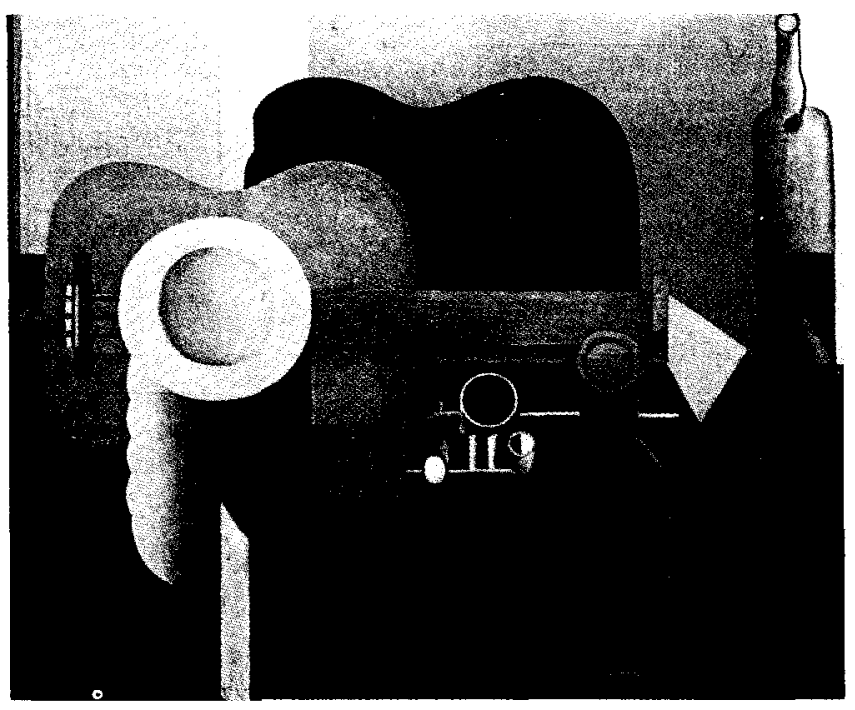

Fig. 4. Still life with stacked plates, Le Corbusier, 1923.

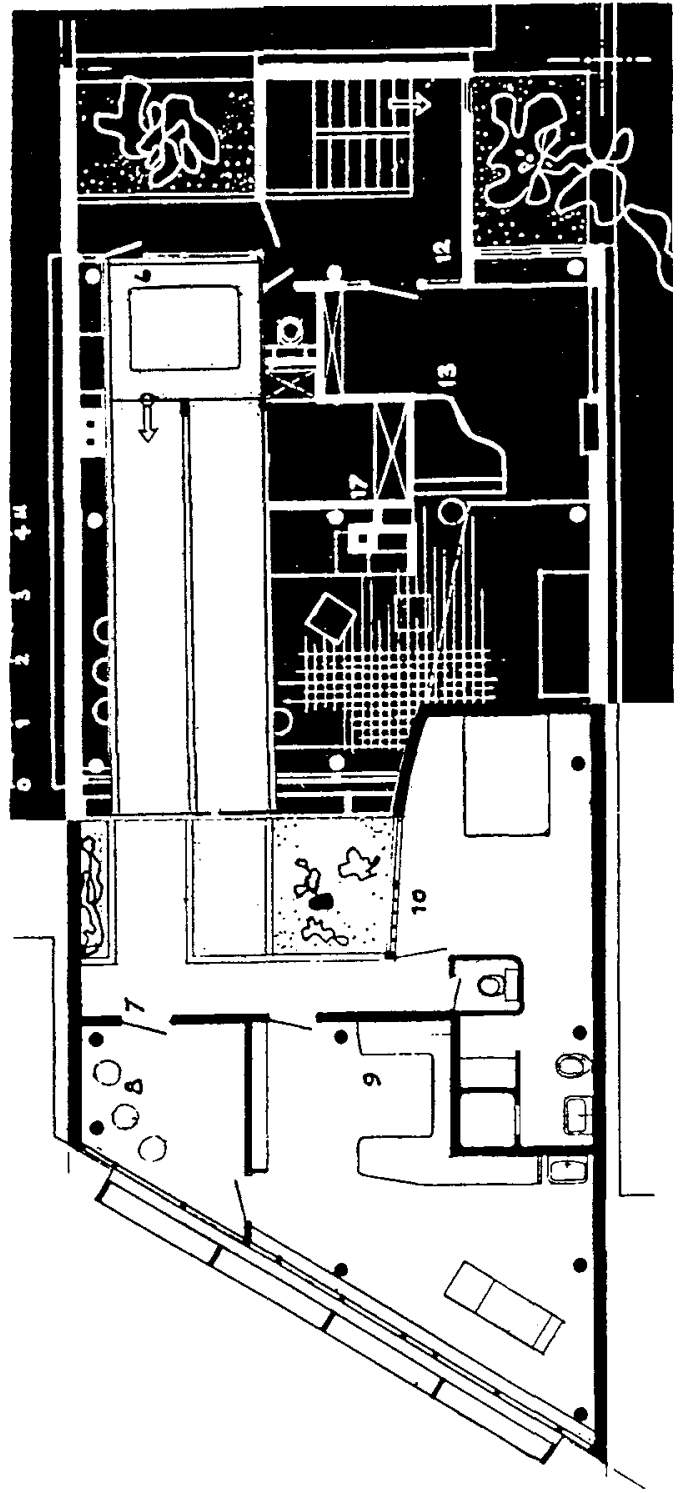

Fig. 5. Maison Curutchet, composite floor plans 
spatial slicing of Purist paintings. From front to back, we may read Maison Curutchet's spatial layers as composed by:

- clinic's brise-soleil and pan-de-verre

- ground floor entry-space/ clinic's rooms/terrace and baldachino

- hanging garden/ void and bridge over maid's rooms

- dining, fireplace, double-story over the living/ bedrooms

- kitchen/ vestibule/ bathrooms and master-bedroom

- stair-tower and open shafts.

Meanwhile, the ramp opposes this vertical stratification of space cutting perpendicularly across them in an ascending movement that ties, and compresses together, the spatial vertical slicing. It is again in the building's façade, the artist's canvas, that the Purist aesthetic discourse becomes absolutely clear. In Maison Curutchet's façade the two nearly identical brise-soleils partially juxtapose, while the roof of the terrace's baldachino provides a visual continuity, and extension, to the dwelling's concrete grid. This double operation of juxtaposition and extension (or continuation) forces the visual compression of the space that separates the two brise-soleils, not only defying the physical distance that separates them, but also presenting them within the same visual field rather than one as foreground and the other as background. Moreover, the presence of the baldachino drastically reduces the luminosity of the tall adjacent blank wall, which, otherwise, would have allowed to read the correct distance between the two brisesoleils, and thus restored them as two differentiated grounds. Furthermore, as part of the same operation of spatial compression, the light that pours through the hanging garden illuminates the baldachino and the pilotis from the rear, providing them with a rather uniform light (another characteristic of Purism) that telescopes the whole composition upon the frontal plane. Thus the building appears to be compressed within a rather thin layer of space that challenges the dominant depth of the site.

The building also clearly exhibits the architect's preference for determined compositional strategies derived from painting and from his wide range of interests. Le Corbusier's Purist paintings show, as Robert Slutzki pointed out, a predominant horizontal composition counterpointed and held in equilibrium by vertical elements, as well as a preference in the utilization of certain proportional systems, ${ }^{8}$ the latter obviously derived from and related to his interest in mathematics and proportional systems, in particular the golden section, which led him, not long before the design of Maison Curutchet, to develop the Modulor.

In correspondence again with his painterly principles, the overall composition of Maison Curutchet's façade consists of a sequence of vertically layered horizontal bands: the dark band of the ground floor, the clinic's brise-soleil + pan-deverre, and then the dwelling's brise-soleil + pan-de verre, established as differentiated planes corresponding to different, yet related, components. Even the composition -or partitioning - of the brise-soleils and pan-de-verres reinforce a predominantly horizontal composition. These horizontal bands, are "checked" (to borrow Robert Slutzki's term) by two punctual vertical elements: the concrete gate and the terrace's baldachino, two elements that establish a conceptual symmetry and diagonal tension to the composition, yet two other characteristics of Purist painting. ${ }^{9}$

Furthermore, the composition of the façade is controlled by a proportional system of regulating lines (a regular feature in Le Corbusier's building façades), and by the dimensions derived from the development of the Modulor, which, in Maison Curutchet, was for the first time implemented and tested in a single family dwelling.

In short, in the façade of Maison Curutchet Le Corbusier exposes the whole scope of his architectural discourse. In the calculated sequence of planes of the building's façade, both the urbanistic and the aesthetic discourses intersect. The façade becomes a condenser of ideas, an element of synthesis, where the generation of the plan as a metaphor of the city, and the spatial layering typical of Purist aesthetics merged into one single thick, yet light and permeable, plane.

\section{THE CONTEXTUAL URBANITY OF MAISON CURUTCHET}

Maison Curutchet is one of the most remarkable examples of Le Corbusier's concern with the insertion of a building in its environment, whether urban or rural. If, as we have seen in the previous section, the compression of the building's components exhibits the influence of his painting activity in his architectural work, the decompression of the same elements uncovers the implicit urban contextualism of the project. The precise location and configuration of those components (brisesoleils, baldachino, pilotis, etc.) contribute to insert the building in the urban character of the street's façade and may be understood as an intentional and direct response to the specific characteristics of neighboring buildings.

As early as the beginning of the design process of Maison Curutchet, in early February 1949, Le Corbusier realized that the site information sent earlier by Dr. Curutchet was insufficient. Therefore, he requested more detailed information showing particular interest in the characteristics of the adjacent buildings that were visible in the two site photographs that Dr. Curutchet had included in the original information package. ${ }^{10}$

The conceptual resolution of the project, that is, the disposition of the two main volumes and the longitudinal section, had been defined in early to mid-February 1949 , that is, within a few days of work. Then, the team AujameHoesli, constantly supervised by Le Corbusier, dedicated to test and refine every aspect of the project in a process that involved simultaneous studies at various scales, as well as several revisions of numerous components. It is precisely in that process that the elements hinted in the initial small scale sketches - the sequence of solids and voids, a protective roof over the terrace, the juxtaposing brise-soleils, the concrete gate-accommodated to each other as well as to the specific characteristics of neighboring buildings in a process that finally inserts the building as a transition between the two 
clearly different existing neighbors. In spite of occupying and demarcating the street property line with the fence, gate and clinic's brise-soleil, establishing a critical continuity to the western building's façade, the perception of the building is of one that accompanies the already existing configuration of the street façade.

Two elements were fundamental in that process: the composition of the façade of the clinic's volumes (the "dark" access band, the floating brise-soleil ) and the baldachino. The brise-soleil, which in this period began to become a trade-mark of Le Corbusier's work, was, from a practical point of view, a means of counteracting the negative impact of direct sunlight on the pan-de-verre. However, its role as an architectural element far exceeded its practicality for, as Alan Colquhoun pointed out:

it was more than a technical device; it introduced a new architectural element in the form of a thick permeable wall, whose depth and subdivisions gave the façade the modeling and aedicular expression which had been lost with the suppression of the window and pilasters. ${ }^{.1}$

In Maison Curutchet, the clinic's brise-soleil is a plane that, however slightly detached from the street line, not only establishes a continuity to the front plane of the façade of the adjacent (western) building, but also, by floating above the ground level, demarcates the ground floor as a differentiated area, a carved out space that provides a certain visual continuity to the set-back, carved out, frontal portion of the more-modern building on the other side. The baldachino, contributes in accompanying the spatial movement of the street's facade, leaning next to the adjacent building's tall wall, operating as a visual transition to the different scales of the two adjacent buildings. ${ }^{12}$

Together, the brise-soleil and the baldachino produce a play of lights and shadows that effortlessly merges with the play of lights and shadows of its neighbors. Thus, all the design elements of Maison Curutchet, but especially the two most distinct elements that conform the frontal volume/s, the brise-soleils, the baldachino (pilotis +protective roof) operate to complete the street's façade without submitting (surrendering) to the characteristics of its adjacent buildings; in other words, without compromising the implementation of the modern techniques, materials, vocabulary and spatial conception that constituted the body of Le Corbusier's architectural discourse.

In conclusion, in the façade of Maison Curutchet (the facade understood as the plane where the totality of the building components collapse together upon the observer's visual field) Le Corbusier lets us read the whole scope of his architectural discourse. The façade becomes the physical element that visually explains, not unlike a didactic demonstration, his urban planning principles and his aesthetic discourse for the new epoch. Nevertheless, far from becoming an isolated, self-referential object, the building is sensitive to the particularities of its surrounding context, confirm-

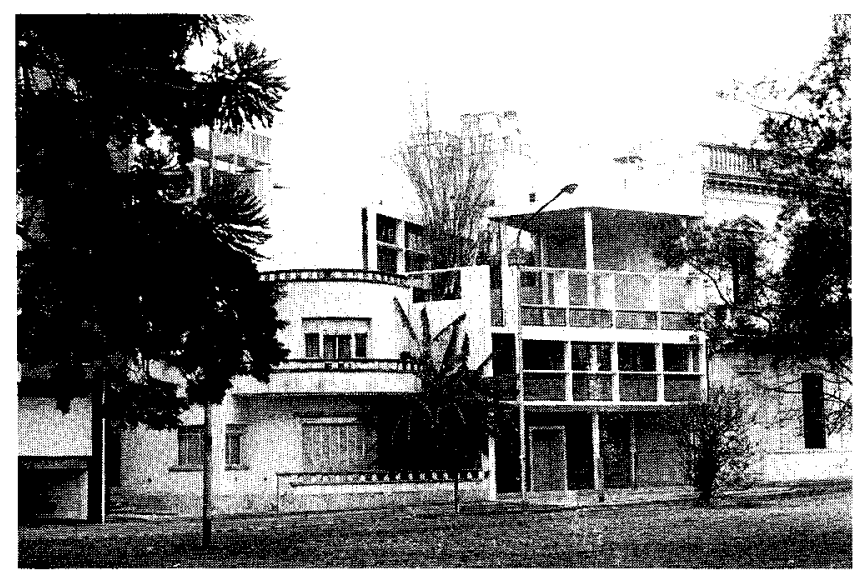

Fig. 6. Maison Curutchet in its urban context. View from the park.

ing that, contrary to what is often asserted, Le Corbusier was one of the modern architects who gave great importance to the contextual insertion (whether urban or rural) of his buildings.

Thus, Maison Curutchet stands as one of the most remarkable examples of the timeless synthesis achieved by Le Corbusier in fully articulating a modern architectural, urban, and aesthetic discourse within an urban site, reaffirming the urban condition of modernity.

\section{NOTES}

1 William Curtis, Le Corbusier, Ideas and Forms, Rizzoli, New York, 1986, page 225.

2 This crossbreeding had been already very fruitful in the twenties, as it may be seen in a large number of buildings (mostly houses) such as Maison Cook (Boulogne sur Seine, 1926), Maison Planeix (Paris, 1927), Villa Stein-de Monzie (Garches, 1927), Villa Baizeau (Carthage, 1928), Villa Savoye (Poissy-sur Seine, 1929) and others. In fact, Maison Cook, and to a lesser degree Villa Baizeau, may be considered as the most direct Corbusian precedents to Maison Curutchet.

${ }^{3}$ Dr. Curutchet had initially contacted an architect from Buenos Aires, Argentina's most important city, who never responded to his request. After some time, Dr. Curutchet considered that his site and program could be best interpreted and resolved by a modern architect, "an architect like Le Corbusier." (from an interview with Dr. Curutchet by Daniel Casoy, published in Projeto \#102, August 1987, São Paulo, pages 92-96). Dr. Curutchet's sister and mother, who traveled regularly to Europe, visited Le Corbusier in his Parisian atelier. They considered the atelier dusty and ill-organized, but, nevertheless, delivered Dr. Curutchet's request and information package to the architect.

${ }^{4}$ For a very good treatment of this point see Pancho Liernur \& Pablo Pschepiurca, "Precisiones sobre los proyectos de Le Corbusier en Argentina, 1929-49; in Summa \#243, Buenos Aires, November 1987, pages 40-55. Liernur \& Pschepiurca's essay is, to-date, the most important critical study of Le Corbusier's projects in Argentina.

5 It is not the objective of this paper to present a full-scale discussion of the architect's urban-planning principles. These are only some of the main characteristics of Le Corbusier's urban-planning, those that are relevant to this discussion of Maison Curutchet. 
${ }^{6}$ One version of the project during the initial weeks of the design process hints at the possibility of recuperating the top of the dwelling too. However, the building was already too tall, and the potential use of the dwelling's roof as a leisure activity was questionable (too much effort was required to climb to the top); therefore this line of investigation hinted in one section drafted by Bernard Hoesli was soon abandoned in favor of only one terrace above the clinic's volume.

7 For excellent discussions on Le Corbusier's painting activity and Purism see "Chapter 2: Purism," in Stanislaus von Moos, Le Corbusier: Elements of Synthesis, MIT Press, Cambridge, 1985, pages 37-56; see also William Curtis, op. cit., especially Chapter Four: "Paris, Purism and L'Esprit Nouveau," pages 48-57.

${ }^{8}$ Robert Slutzki, "Après le Purisme," in Assemblage 4, pp. 94-101.
9 Ibid.

${ }^{10}$ The two adjacent buildings are fundamentally different. The western neighbor is a two-story building, leaning on the street property line, with a tall, flat italianate/classicist façade. The eastern neighbor is a "more modern," lower, two-story building set back from the street property line, and featuring a small garden in front of it.

"Alan Colquhoun, "The Significance of Le Corbusier," in The Le Corbusier Archive, volume 1, Garland Publishing and La Fondation Le Corbusier, London and Paris, 1982, page xlii.

12 In the final project and its built version the baldachino's roof covers only one-half of the terrace surface. However, previous schemes contemplated a roof covering of the entire front of the terrace like in Maison Cook. 